\title{
CORPORATE CODES OF ETHICS: STRUCTURAL, PRAGMATIC, AND COGNITIVE ASPECTS
}

\section{Shypitsyna Yu. V.}

\section{INTRODUCTION}

Studying language as an integral part of social reality has stimulated the increase of interest among numerous scholars in the language of business communication as an essential part of human activity (Jurgen Habermas ${ }^{1}$, D. Crystal ${ }^{2}$, N. Fairclough ${ }^{3}$, S. Herring ${ }^{4}$ etc.). Business communication includes texts related to the regulation of business communic ation, such as codes of ethics (or codes of business conduct). The knowledge of and adherence to the international standards of business conduct are becoming increasingly important in the era of globalization. A code of ethics describes rules of business conduct which should be followed by everyone who is directly related to the internal and external activities of the company.

Since corporate ethics is gaining significance in the business world today, the study of the language of codes of ethics is of actual relevance. Companies create codes of ethics to establish and articulate corporate values, responsibilities, and ethical aspirations of the organization, as well as the mechanisms for introducing corporate employees to the ethical principles espoused by the company. Our research is focused on texts of the codes of ethics of American corporations within the framework of their linguistic and extra-linguistic factors, such as structural organization, pragmatics, and semantics.

A corporate code of ethics as a special type of regulatory or normative document has not yet received a thorough study in modern linguistics. Research of the codes of ethics is mainly focused either on their extralinguistic aspects, namely, social and economic factors of business ethics ${ }^{5}$;

${ }^{1}$ Habermas J. The Theory of Communicative Action. Vol. 1. London : Heinemann, 1984. $465 \mathrm{p}$.

${ }^{2}$ Crystal D. Language and the Internet. Cambridge : Unversity Press, 2002. 272 p.

3 Fairclough N. Language and Power: Second Edition. Harlow, England : Pearson Education, 2001. $226 \mathrm{p}$.

4 Herring S. Computer-Mediated Communication: Linguistic, Social and CrossCultural Perspectives. Amsterdam, Philadelphia : John Benjamins, 1996. 136 p.

${ }^{5}$ Bommer M., Gratto C., Gravender J., Tuttle M. A Behavioral Model of Ethical and Unethical Decision Making. Journal of Business Ethics. 1987. No. 6. P. 265-280. 
or the national character of ethical codes ${ }^{6}$; or the problem of efficiency and appropriateness of ethical conduct ${ }^{7}$; or the typology of ethical is sues raised in the codes ${ }^{8}$. Other studies deal with the analysis of the language in the texts of the codes of ethics (H. Farrell ${ }^{9}$, I. Pollach ${ }^{10}$ ). However, the studies do not look into the prescriptive nature of the texts, nor their pragmatic, semantic, and sociocultural characteris tics.

Conceptual analysis as a special method of linguistic analysis has been used to identify the main concepts of codes of ethics. It includes analysis of dictionary definitions, contextual analysis, etymological analysis, component analysis, as well as frame and metaphorical modeling of the main concepts of the codes. General scientific methods, including hypothetical and deductive method, as well as discourse analysis have been applied to identify the main features of the types of discourse used in the codes of ethics, while functional analysis helped identify major and minor functions of the codes of ethics.

\section{Structural and pragmatic features of codes of ethics}

Codes of ethics, as a means of influencing a person's value system, touch upon important ethical issues that arise in the sphere of business, employing ethical discourse, which is a coherent process of interpersonal communicative interaction. A code of ethics is an official document of a company in which the corporate principles and rules of conduct for its managers and employees are stated. Analysis of the codes showed that, unlike other legal documents, corporate codes of ethics do not have a clearly defined form and vary in their structure, size, and content, ranging from a few paragraphs to a few dozen pages. Codes of ethics may be:

1) corporate credo (general provisions on the ethical way of doing business: mission statements, a set of business principles, mission, vision, values, etc.). These codes are formulated as a set of ethical principles that a company promises to follow in its business: honesty, integrity, trust, res pect etc.

${ }^{6}$ Langlois C.C., Schlegelmilch B.B. Do Corporate Codes of Ethics Reflect National Character? Evidence from Europe and the United States. Journal of International Business Studies. 1990.Vol. 21. No. 4. P. 519-539.

${ }^{7}$ Case J.H. Ethics? For Some Executives, It's All About Image. UW Business. Spring, 2003. P. 36-37.

8 Mathews M.C. Codes of Ethics: Organisational Behaviour and Misbehaviour. Research in Corporate Social Performance. 1987.Vol. 9. P. 107-130.

${ }^{9}$ Farrell H., Farrell B. The Language of Business Codes of Ethics: Inplication of Knowledge and Power. Journal of Business Ethics. 1998. No. 17. P. 587-601

${ }^{10}$ Pollach I. Communicating Corporate Ethics on the World Wide Web. A Discourse Analysis of Selected Company Web Sites. Frankfurt am Main : Peter Lang, 2003. 236 p. 
2) rules of ethical conduct (a code of ethics, a code of conduct, etc.) that regulate various aspects of business activities, referring to situations involving moral choice: relationships with customers and suppliers, conflict of interest, prohibition against bribes, employee rights and duties, environmental issues, confidential information etc. Large corporations (Procter \& Gamble, Coca-Cola, Motorola, Hewlett-Packard, Ernst \& Young) tend to create detailed in content and large in size text of the code, which combines a general ethical view of how their business should be conducted, as well as their employees' ethical behavior. The overall structure of the text includes: the title; the preamble (introduction by the President of the company and setting forth the ethical principles that guide the company); the main content part - a consistent presentation of rules; and the final part further provisions and information about the company.

Creating a code of ethics is determined by communicative and pragmatic aim which draws upon the arsenal of linguistic resources and depends on pragmatic factors, such as the interaction between the addresser and the addressee, modality, evaluation, various strategies and tactics etc. The defining characteristic of the texts of the ethical codes is that they have a dual addressee:

1) direct addressee - employees of the company to whom the rules and regulations of the code are directed;

2) indirect addressee - various entities that are directly and indirectly related to the business of the company: existing customers, suppliers, shareholders (direct relationship) and the general public as potential customers (indirect relationship).

The presence of the dual addressee determines the dual pragmatic aim of the texts: on the one hand, it is the conscious specific intention of the companies' management to set ethical standards in business communication, as well as to regulate and influence the addressee's behavior; on the other hand, it is self-presentation and self-promotion of the company. These factors determine the pragmatic content of the texts of the codes of ethics which is expressed by two types of modality: for the subject of speech, an alethic modality is implemented in the form of descriptive statements; as to the addressee, a deontic modality is used in the form of prescriptions. Deontic modalities are related to the mechanisms of regulating human behavior through a system of rules and norms; however, alethic modalities characterize statements about the world in terms of truth/untruth.

The use of descriptive statements is explained by the intention of the companies to present themselves ethically oriented, complying with the rules of corporate ethics. By promulgating their own corporate code of ethics, companies indirectly provide the general public with information about the positive foundations of their business. The Present Simple Tense, in which 
alethic statements are expressed, affirms the truth of the content of the utterance. For example: We provide our employees full opportunity <...〉. Mannatech strives to c create an environment, which understands, fosters and embraces the value of diversity (Mannatech).

The present form of the verbs (provide, strives, understands, fosters, embraces) reinforces and complements positive true statement. Unlike Present Continuous, Simple Present does not bind the modal value to the moment of speech, but enhances the consistency and permanent state of the utterance.

The means of expression of the deontic modality in the texts of the codes of ethics (modal verbs and their equivalents, infinitive structures, words and phrases with a modal component) are used to influence the direct addressee's behavior, as a result of which company employees are obliged to follow the rules of the code of ethics. For example: You must comply with generally accepted accounting principles. You have a responsibility to HP to ensure that your business activities do not violate applicable antitrust and competition laws (Hewlett Packard).

The attributive regulatory nature of the English text of the code of ethics is expressed by the following words and phrases: it is required to, it is our obligation, it is imperative, it is very important, it is the Company's policy, to have a responsibility, to be committed, to be responsible for, to be obligated to. They express the meaning of necessity, order, and prohibition; their usage is pragmatically conditioned since they emphasize the obligation and the importance of compliance with the rules prescribed by the code. Additionally, they can be correlated with the modal verbs must and shall, which are considered highly categorical in their nature. The phrases it is strictly prohibited/forbidden/it is unacceptable are synonymous with the modal verbs must not/shall not/will not. For example: Personal loans to executive officers are strictly prohibited and will not be made under any circumstances (Mannatech).

Moderately categorical statements are conveyed by the phrases it is expected, it is recommended, you are encouraged to, which correlate with you should, you may, while the phrases it is against the law, it is prohibited/forbidden/illegal/unethical correlate with the modal expression you may not, for example: Each of us is expected to demonstrate these key beliefs in our work as Motorolans (Motorola). The provisions of this Code are recommended for observance by all subsidiaries (OJSC Alfa Bank).

The texts of the codes of ethics differ from other normative texts by the fact that they allow the use of expressive means by which the addressee's social position and behavior are influenced. The wide range of verbal and non-verbal means of assessment reveal that the code of ethics not only establishes norms and regulates the behavior of the addressee, but also, to a 
certain extent, serves as a self-assessment and self-presentation of the company. Self-assessment in the texts of the codes is represented by the specifics of the code's chronotope content, positive self-description and nonverbal graphic means.

Chronotope markers emphasize that creating a code of ethics ensures the reliability and viability of the company, its high reputation, tested over time. For example: At Johnson \& Johnson there is no mission statement that hangs on the wall. Instead, for more than 60 years, a simple, one-page document - Our Credo - has guided our actions in fulfilling our responsibilities (Johnson \& Johnson).

Positive self-description is reflected in the statements about the company, which sound like advertisements of these companies or resemble advertising slogans by their form. Usually, they contain vocabulary with a positive connotation, which can be contrasted with lexical units with a negative evaluative content, for example: We will not tolerate activities to achieve results through illegal or unethical deals anywhere in the world (Procter \& Gamble) - creates a positive image of a company that expresses intolerance towards illegal and unethical acts by using double negative (particle not and prefixes il-, un-).

Non-verbal graphic means of text - photos of happy, contented employees of the company, which shows the company's friendly atmosphere, as well as the font, highlight what is important for the addressee and helps to create a positive impression of the company. One example is the phrase "No one at any level of the Company has the authority to require or permit you to violate the law", used in the Procter \& Gamble's code of ethics, where the words require and permit are in italics and bold indicating compliance with the law, the company's reliability and its serious intentions.

During the process of communication in order to regulate the addressee's behavior, the addresser typically resorts to a variety of strategies and tactics. A strategy refers to a set of speech actions aimed at achieving the communicative goal. Choosing a particular strategy does not yet guarantee the achievement of the set goal. The overall result of strategy implementation depends on an adequate and successful combination of various tactics as a way of strategy implementation. A tactic describes specific speech actions that influence the addressee.

In the codes of ethics hard and soft strategies have been distinguished based on the way of influencing the addressees. The addresser of the code, while ignoring the principle of politeness, applies hard strategies to influence the direct addressee through the choice of categorical verbal means. However, soft strategies involve establishing good interpersonal relationships, collaborating with the addressee, and aiming at solving the tasks in common. 
In the texts of the codes of conduct, hard strategies are implemented by various tactics: tactics of domination, tactics of alienation, tactics of threat, and tactics of prohibition. For example, the tactics of domination in the codes are implemented through modal verbs and their equivalents with a highly categorical meaning, as well as through imperative and affirmative sentences. This choice of language is aimed at maintaining subordination of the addressee: You must avoid any activity or arrangement that could compromise your judgment or objectivity in the performance of your duties with Shell. It is critical that you conduct your employment activities objectively. The above statements are characterized as status labeled, in which the dominant addresser dictates to the addressee a certain line of behavior (you must avoid any activity or arrangement that could compromise...; it is critical that you conduct...).

Along with hard strategies that reflect the authoritarian nature of the addresser's relationships with the addressee, the codes of ethics present strategies of a less categorical nature, which are defined in this research as soft strategies. Soft strategies are a set of tactical techniques used by the addresser of the code to engage the addressee in cooperation. Soft strategies are implemented by using a variety of tactics: solidarity tactics, tactics of emphasizing the emplyees' importance, tactics of self-reflection, tactics of creating a positive image, tactics of argumentation, tactics of encouraging open dialogue and tactics of politeness.

For example, solidarity tactics are used to emphasize the equality in relations between the addresser and the addressee, thereby concealing the background of the addresser's higher status role. This tactic is accomplished in the following ways: 1) by using inclusive personal pronouns we, our, each of us: Just as we expect others to honor our intellectual property rights, we must honor the rights of others (Hewlett Packard); 2) by using the company affiliation markers, such as artificially created generic staff name Motorolans: Each of us is expected to demonstrate these beliefs in our work as Motorolans (Motorola).

The choice of strategies depends on the style of leadership adopted in the company and the type of addresser-addressee relationship, which can be either subordinate or cooperative. If the addresser has subordination relationships with the addressee, then the addresser, as a higher status holder, may simply require the addressee to adhere to a certain line of behavior, using hard strategies aimed at enhancing the perlocutionary power of expression and thus making it more persuasive to the addressee. At the same time, in cooperative interaction between the addresser and the addressee, preference is given to soft strategies, which are mainly aimed at motivating the addressee. 
On the basis of the above pragmatic features, two types of codes were distinguished: internally oriented and externally oriented. Intern ally oriented codes are formulated for the company's employees. Such codes are based on the rules and regulations of business ethics and focus on compliance. In this type of codes, there is a clear subordination of the addresser-addressee relationships. They are also characterized by a deontic modality, hard strategies, categorical directive speech acts, and adherence to the cooperation principle by the addresser.

However, externally oriented codes are addressed to the general public, that is, to the potential customers. They provide a positive description of the company (self-promotion) and emphasize cooperation between the company and its employees. Such codes predominantly have alethic modality, positive self-description, soft strategies, non-categorical directive speech acts, as well as adherence by the addresser to the principle of politeness.

\section{Main concepts of codes of ethics as expression of business values}

A code of ethics, which articulates a specific set of corporate values, generally includes such traditional virtues as: integrity, trust, loyalty, commitment, honesty, and respect for one another, as well as avoiding conflicts of interest. Additional values may also include newer elements, such as: innovation, teamwork, customer focus, and continuous improvement. Scholars maintain that codes as expressions of values are an integral part of corporate ethics, therefore the addresser of the code uses fundamental business values in order to create a positive image for the company ${ }^{11}$.

The conceptual system of codes of ethics is a set of basic concepts that categorize knowledge in the field of business ethics. It includes four main concepts which the writer of the code of ethics uses. The central position in the system belongs to the concept of COMPANY. It performs the function of unifying and linking all the other interrelated concepts, which are REPUTATION, SUCCESS, and INTEGRITY. The abovementioned concepts are different in their nature. COMPANY, REPUTATION, and SUCCESS are characterized by a social dimension, while the concept of INTEGRITY is characterized by a purely ethical dimension.

The metaphorical analysis of the concept of COMPANY has revealed that the writer of the code uses metaphors of personification in order to present the company in the most favorable light. As a result, the inanimate object "company" is endowed with human qualities as if it were an actual

${ }^{11}$ Cox D., La Caze M., Levine M. Should We Strive for Integrity. Journal of Value Inquiry. 1999. Vol. 33. No. 4.

P. 125-141. 
human being who acts as a social entity. For example: "Cummins is committed to quality, innovation and integrity". "What is Otis doing to apply and strengthen ethical business practices worldwide?". "Mannatech shall not knowingly or willfully infringe the valid intellectual property of any party or breach its obligations of confidentiality with any party".

The following expressions is committed to/is doing to apply and strengthen ethical business practices/shall not knowingly or willfully infringe along with the proper nouns Cummins, Otis, Mannatech personify the companies as living beings who play the role of a social entity with social responsibilities.

Here is another example of personification in the code of the Cadbury Schweppes Company: "Ethical business sits at the heart of Cadbury Schweppes". Having taken on the image of a living being, the company is portrayed in the code as having a human body. Cadbury Schweppes "has a heart" as if to emphasize the company's priority of the ethical approach to doing business.

Further analysis of the codes of ethics has revealed that the concept of COMPANY is always presented as a positive and useful member of society. The writer of the code gives the company one of the following roles: a steward, a role-model citizen, or a leader. To create a positive image of the company, the writer uses various figures of speech and descriptive words, such as the following examples: “...to recognize our position as stewards of our customers' business. To place the best of our thinking, energies and abilities into supporting customer enterprises" (Lockheed Martin). "We serve society by providing life-enhancing products and services at a fair price, and by actively supporting the communities in which we operate”(Motorola), “...we reflect the diverse world we serve... ", “...giving back to the people we serve..." (Levi Strauss). As we can see from these examples, some companies want to be perceived by the reader as stewards doing everything within their power to support the communities' welfare.

Other companies are trying to create an image of a perfect citizen. Here are some examples: "We must be good citizens - support good works and charities and bear our fair share of taxes. We must encourage civic improvements and better health and education" (Johnson \& Johnson).

However, the company McDonalds prefers the leadership role: "...being a leader in social responsibility", "We realize that in today's world, a business leader must be an environmental leader as well... We will lead, both in words and deed", "We take a leadership role in education matters".

Thus, the writer of the code of ethics uses metaphors of personification to endow the company with human qualities, emphasizing the role the company plays in the society acting as a servant, a role-model citizen, or a leader. 
Ethical concepts, on the other hand, serve as motivators, incentives, and even excuses for certain actions, as well as serving as criteria for performance evaluation. The capacity to form ethical perceptions and to apply those perceptions in real-life situations is arguably one of the most important features of a human individual or of a society as a whole, in the sense that it has a bearing on all spheres of life.

When all of the separate elements which are part of the ethical perceptions of an individual or of a society are viewed as a whole, they may ultimately be referred to as "universal ethical concepts". Universal ethical concepts are the essence of ethics of the individual and society, their actual semantic content is dynamic and depends on time, economic, ethnic and cultural, social, political, psychological and other factors.

An analysis of the concept of INTEGRITY has enabled us to consider the basic business values that are embodied in a code of ethics. The choice of the concept has not been arbitrary - INTEGRITY is considered by a number of scholars to be the most fundamental ethical value ${ }^{12}$. This concept is represented by means of numerous nouns and adjectives which express the social and ethical evaluation of the addresser of the code of ethics.

We have observed the following pattern: the more significant for the addresser the value is, the greater the number of synonyms used by the addresser in the code to express it. That is the reason why the concept of INTEGRITY is expressed by an elaborate system of synonyms and phrases, such as honesty, the highest ethical standards, respect, justice, trust, commitment, responsibility, fairness. For the addresser of an ethics code INTEGRITY is the foundation of the company, which determines its reputation, as reflected in the following phrases: integrity is "an enduring value", "our most valuable asset", "fundamental principle", "at the core of the values", "strong foundation", "essential to ethical business practices", "at the heart of the company's philosophy", "fundamental basis", "...underlies how we compete in the marketplace and how we behave", "...forms the basis for all of our relationships", "the highest standards/degree/sense/level of integrity".

Thus, the analysis based on the codes of ethics has revealed that the addresser of the code considers INTEGRITY to be the most fundamental and all-encompassing business value. The addresser uses metaphors of personification to endow the company with human qualities of a servant, a role-model citizen, or a leader. The concepts COMPANY, REPUTATION, and SUCCESS are socially determined, whereas the concept of INTEGRITY

${ }^{12}$ Putman D. Integrity and Moral Development. The Journal of Value Inquiry. 1996. No. 30. P. 237-246. 
has a purely ethical dimension. Further research will be focused on the concepts of REPUTATION and SUCCESS.

Since corporate social responsibility takes into account the long-term interests of customers and society, every company's long-term success is built upon its reputation. Only those companies that know and abide by the rules of trade and fair competition, as well as value one of the most important elements of success - their reputation, their good name - can expect to achieve success.

The codes of ethics that underpin the social and ethical principles of business conduct indicate that, in the addresser's worldview, the concept of INTEGRITY correlates with the concepts of REPUTATION and SUCCESS. These concepts are semantically similar, as the ethical behavior of employees contributes to building a good reputation for the company, which, therefore, leads to success. The reputation, and, subsequently, success of the company, depend on the customers' trust and loyalty. Therefore, the following semantic chain can be built: INTEGRITY> REPUTATION>SUCCESS. If INTEGRITY is a component of REPUTATION, then REPUTATION is a component of SUCCESS.

The above is supported by examples where all three concepts are interconnected and can be used in the same context. For example: "Yes, Alliance \& Leicester believes that the path to success lies in honest relationships and high standards of business ethics: "success through fair dealing and high standards of business integrity" (Alliance \& Leicester). "Integrity in everything we do is essential to Cummins' ability to deliver an excellent and sustainable long-term return to our shareholders. Conducting our business with integrity - honestly and fairly - will earn repeated business from our customer's (Cumming Energy). "An excellent and sustainable long-term return" verbalizes the SUCCESS concept, whereas "earning repeated business from our customers" (i.e. to earn good reputation with customers) acts as a verbalizer of the concept of REPUTATION.

The analysis of the texts made it possible to establish that, according to the addresser of the code, success depends on the following factors: 1) how ethically oriented the company is in its activity (ethics); 2) the quality of work of the company's employees (performance); 3) how the company treats its employees and what kind of working conditions it creates for them (people, employees, team). Accordingly, we distinguish the following components of the concept of SUCCESS: BUSINESS ETHICS, QUALITY, and RESOURCE.

Consider how the concept is verbalized at the level of its components. For Hewlett Packard, personal and professional ethics are among the key factors behind success. The company perceives BUSINESS ETHICS as a component of the concept of SUCCESS: "There is no substitute for personal 
and professional integrity; doing well and doing good can go hand in hand; and trust and respect have always been the cornerstones of our success"(Hewlett Packard). The phrases "doing well" and "the cornerstones of our success" represent the concept of SUCCESS, while "personal and professional integrity, doing good, trust, and respect" are components of BUSINESS ETHICS of the concept of SUCCESS.

To be the market leader, Duke Energy Corporation must adhere to high ethical standards: "It's not enough to be strong and big and successful. It is truly a great company, we must conduct our business ethically. We all know where we want to go at Duke Energy - we want to lead the energy industry. We also know how we want to get there - honestly, morally and with integrity. It might not be the easiest way. But for us, it is the only way "(Duke Energy). The example shows that it is important for the company not only to succeed in their activities (to be strong and big and successful; to be truly a great company; to lead the energy industry; to get there) but to do it the right way (to conduct our business ethically; honestly, morally and with integrity; not the easiest way). The contextual closeness and interdependence of the concepts of INTEGRITY and SUCCESS are shown in the following example: "We value performance achieved with integrity... Conducting GSK's business with honesty, fairness, and integrity will ensure our continued growth and success and help us achieve our strategic mission "(GlaxoSmithKline).

Financial success, that is a profit, is the goal of any company, however, some companies associate success with how well customers are satisfied with quality of the company's product. Phrases such as customer satisfaction, to satisfy customers and improve profitability highlight QUALITY as the second component of the concept SUCCESS. For example: "Customer satisfaction will be the measure of our success" (Cummins Engine). "We encourage our employees to use their own initiatives to satisfy customers and improve profitability... We must pursue excellence in the quality of each product, service and contact... Our success depends upon the achievement of excellence" (Coca Cola).

In the codes of First Federal and Sybase, for which honest work is based on success, there is a number of linguistic tools that represent the QUALITY component of the concept of SUCCESS. For example: <...> full, fair, accurate, timely and understandable disclosures in First Federal's periodic reports are legally required and essential to the success of your business (First Federal). All employees are expected to contribute to the success of Sybase by performing their jobs as required and conducting themselves in a professional manner consistent with the company's business philosophy, values and standards of business conduct (Sybase). 
Williams-Sonomainc argues that in order to be successful (to succeed, we live by a short, but important list of values), the company employees must live by certain important principles, one of which is quality of their products and services, which should be the pride of the company (We must take pride in everything we do). For example: "Quality: We must take it and everything we do. From our people, to our products and to our relationships with business partners and our community, quality is our signature" (WilliamsSonomainc).

The factors that contribute to success (the key to our success; can be successful and achieve; the potential of our company) are the employees and the customers of the company (our employees, the corporate team, the best people available; People First; our associates and their imagination; customers ... without them nothing else matters), as well as the atmosphere in which they work (respectful, creative, and positive atmosphere where employees can be successful; an environment that attracts, motivates and recognizes high performance).

In the following example, RESOURCE, the third component of the concept of SUCCESS, is illustrated: Since our employees are the key to our success and we are all part of the corporate team, By providing a respectful, creative, and positive atmosphere where employees can be successful and achieve, Sybase is capable of attracting, motivating, and retaining the best people available (Sybase).

Metaphorically, this concept, like the concept of INTEGRITY, is modeled as a foundation or building (threaten the foundation, strong foundation, to build on a foundation, to undermine the foundation, cornerstone, keystone to success), for example: Together this code and the Compliance Program set an ethical tone for Conducting business and reinforcement Mannatech's commitment to integrity. Since its inception, the keystone of Mannatech business success has been integrity with respect to its dealings with its Independent Distributors and customers (Mannatech). SUCCESS in this example is a building, the cornerstone of INTEGRITY, which shows the interdependence of the concepts.

Thus, an analysis of the contexts of use of verbalizers of SUCCESS made it possible to distinguish its three components: BUSINESS ETHICS, QUALITY, and RESOURCE. The concept of SUCCESS in the addresser's worldview correlates with the concepts INTEGRITY and REPUTATION. These concepts are semantically interconnected, forming the following the conceptual chain INTEGRITY> REPUTATION > SUCCESS.

The concept of REPUTATION can be interpreted differently: in the legal aspect, it is considered as a public assessment of a person's activity; in the economic aspect, as a cycle of transactions with a product that leads to the ultimate goal (sales), and the linguistic interpretation includes two meanings: 
1) evaluation (positive or negative); 2) a highly positive opinion about something or someone. Combining the established definitions, we can distinguish two important components of this concept: on the one hand, the reputation of the company includes the evaluation of the production process and the quality of the product as its end result, and, on the other hand, the opinion that customers have about the activity of the companies as a whole. For example: "We damage our good name if we ship products or deliver services that fail to live up to Motorola standards" (Motorola). The phrases "ship products" or "deliver services" indicate a sign of "production process"; while "good name" is the verbalizer of the concept of REPUTATION.

On the other hand, in the texts of the codes, the word "reputation" has the meaning of "a highly positive opinion generally held about a person or thing", for example: "We protect and enhance the reputation, ensuring our continued success... The integrity and professionalism we bring to these challenges, working in our country practices and as part of our global organization, define the reputation of Ernst and Young" (Ernst \&Young).

In conclusion, the concept of REPUTATION consists of two main elements: on the one hand, it is a set of internal qualities and properties of a person, and, on the other, it is a public opinion, an assessment of this set. This means that the company's reputation includes the process of production and quality of the product as its end result, as well as the opinion that customers have about the company's activities as a whole. The concept of reputation is used by the addresser of the code in order to create the image of a powerful company which is able to fully satisfy its customers.

The chapter analyzes some of the major concepts of the conceptual system of "business ethics" based on the codes of ethics developed by American companies. Analysis of the concepts of INTEGRITY, COMPANY, REPUTATION, and SUCCESS has enabled us to consider the basic business values that are embodied in the codes of ethics.

\section{CONCLUSIONS}

The research of the codes of ethics, developed by American corporations, has taken into consideration their structural, semantic, content and pragmatic aspects. The addresser/addressee interaction has been explored which allows the distinction of two types of the codes of ethics: internally oriented codes (formulated for employees to ensure their compliance with the rules of business ethics and a clear subordination of the addressee); and externally oriented codes (addressed to the general public, potential customers) that provide self-description of the company for the purpose of self-promotion and emphasize cooperation between the company and its employees. The subordinate type of addresser-addressee interaction is expressed by deontic modality and hard strategies, making it more persuasive to the addressee. 
The cooperative type of interaction between the addresser and the addressee is expressed by means of aletic modality and soft strategies.

A cognitive approach to the study of the semantic features of the codes of ethics makes it possible to reconstruct the concepts of business ethics and, subsequently, identify the conceptual sphere of business ethics, which includes four basic concepts that the addresser of the code of ethics operates in. Central to it is the concept of COMPANY, which performs a unifying function, linking all the other interdependent concepts: REPUTATION, SUCCESS, and INTEGRITY. The concepts of COMPANY, REPUTATION, and SUCCESS are characterized by social orientation, while the concept of INTEGRITY belongs to ethical concepts. In most of the texts of codes of ethics, the concept of INTEGRITY is presented as a fundamental ethical principle. The concepts INTEGRITY, SUCCESS and REPUTATION have some common verbalizers, which indicates that for the addresser of the code these concepts are holistic and interdependent.

\section{SUMMARY}

The article explores codes of ethics, developed by American corporations, from their structural, semantic, pragmatic, and cognitive aspects. The research of the specifics of the addresser/addressee interaction, subordination or cooperation, allows the distinction of internally oriented and externally oriented codes of ethics. The internally oriented codes are formulated for employees to ensure their compliance with the rules of business ethics and a clear subordination of the addressee. However, externally oriented codes are addressed to the general public (potential customers), provide self-description for the purpose of self-promotion and emphasize cooperation between the company and its employees. Within the pragmatic aspect, the means of expression of deontic and alethic types of modality characteristic of ethics codes have been examined. The article also explores some of the major concepts of the conceptual system of "business ethics". The concepts of INTEGRITY, COMPANY, REPUTATION, and SUCCESS, as fundamental business values of the codes of ethics, have been analyzed.

\section{REFERENCES}

1. Habermas J. The Theory of Communicative Action. Vol. 1. London : Heinemann, 1984. 465 p.

2. Crystal D. Language and the Internet. Cambridge : Unversity Press, 2002. 272p.

3. Fairclough N. Language and Power: Second Edition. Harlow, England : Pearson Education, 2001. 226 p. 
4. Herring S. Computer-Mediated Communication: Linguistic, Social and Cross-Cultural Perspectives. Amsterdam, Philadelphia : John Benjamins, 1996.136 p.

5. Bommer M., Gratto C., Gravender J., Tuttle M. A Behavioral Model of Ethical and Unethical Decision Making. Journal of Business Ethics. 1987. No. 6. P. 265-280.

6. Langlois C.C., Schlegelmilch B.B. Do Corporate Codes of Ethics Reflect National Character? Evidence from Europe and the United States. Journal of International Business Studies. 1990.Vol. 21. No. 4. P. 519-539.

7. Case J.H. Ethics? For Some Executives, It's All About Image. UW Business. Spring, 2003. P. 36-37.

8. Mathews M.C. Codes of Ethics: Organisational Behaviour and Misbehaviour. Research in Corporate Social Performance. 1987. Vol. 9. P. 107-130.

9. Farrell H., Farrell B. The Language of Business Codes of Ethics: Inplication of Knowledge and Power. Journal of Business Ethics. 1998. № 17. P. 587-601.

10. Pollach I. Communicating Corporate Ethics on the World Wide Web. A Discourse Analysis of Selected Company Web Sites. Frankfurt am Main : Peter Lang, 2003. 236 p.

11. Cox D., La Caze M., Levine M. Should We Strive for Integrity. Journal of Value Inquiry. 1999. Vol. 33. No. 4. P. 125-141.

12. Putman D. Integrity and Moral Development. The Journal of Value Inquiry. 1996. No. 30. P. 237-246.

\section{Information about the author:} Shypitsyna Yu. V., $\mathrm{PhD}$ in Linguistics (Candidate of Philological Sciences), Associate Professor, Lecturer of Intensive English Program Department University of Dayton 300 College Park, Dayton, Ohio, 45469, USA 